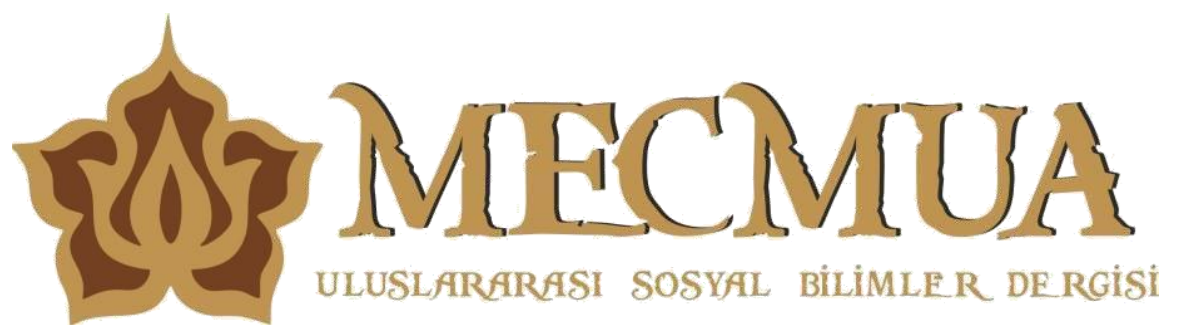

Bahar 2020, Yıl: 5, Sayı: 9, ss. 139-152

Doi Number: 10.32579/mecmua.686342

Araştırma Makalesi / Research Article

Yayın Süreci / Publication Process

Yükleme Tarihi: 07.02.2020 / Kabul Tarihi: 20.02.2020

\author{
Ayşe ASİLTÜRK * \\ Sibel PINAR ${ }^{* *}$
}

\title{
OCCUPATIONAL RISKS AND JOB STRESS OF HEALTH EMPLOYEES: A RESEARCH IN ARTVIN PROVINCE ${ }^{1}$
}

\begin{abstract}
The purpose of this study is to evaluate the relationship between the occupational risks and job stress of health employees, that is, to identify the hazards and risks that health employees are exposed to during the provision of health services, and to determine the relationship of these hazards with their anxiety levels. The universe of the research was 294 healthcare employees working in the Artvin State Hospital (Turkey), where the research was conducted, January - April 2019, and 157 healthcare employees were sampled. According to the data obtained from the questionnaire consisting of Beck Anxiety Scale (BAS) and Health Employee Safety Scale (HESS) questions was analyzed with SPSS 25 package program.
\end{abstract}

Key words: Occupational Risks, Job Stress, Beck Anxiety Scale, Health Worker Safety Scale, Healthcare Sector

* ID Dr. Öğr. Üyesi, Avrasya Üniversitesi, İşletme Bölümü, Trabzon / Türkiye, Email: ayse.asilturk@avrasya.edu.tr

** (D) Avrasya Üniversitesi Sağlık Kurumları İşletmeciliği ve Yönetimi ABD, MBA Mezunu Artvin Devlet Hastanesi, Hasta İletişim Birimi Sorumlusu, Email: sibell108@ hotmail.com

${ }^{1}$ This article was produced from the master thesis titled "Occupational Risks and Job Stress of Hospital Employees: Group B Hospital Case" (Sibel Pinar, 2019), which was prepared for Department of Health Businesses Management / Institute of Health Sciences of Avrasya University.. 


\title{
SAĞLIK ÇALIŞANLARININ MESLEKİ RİSKLERİ VE İS STRESİ: ARTVIN IILINDE BİR ARAŞTIRMA
}

\section{Özet}

\begin{abstract}
$\mathrm{Bu}$ araştırmanın amacı sağlık çalışanlarının mesleki risklerinin iş stresi ile ilişkisini değerlendirmek yani; sağlık çalışanlarının sağlık hizmeti sunumu esnasında maruz kaldıkları tehlike ve riskleri belirlemek, bu tehlikelerin kaygı düzeyleri ile ilişkisini saptamaktır. Araştırmanın evrenini Ocak - Nisan 2019'da araştırmanın yapıldığı Artvin ilindeki devlet hastanesinde görev yapan 294 sağlı çalışanı ve örneklemi 157 sağlık çalışanı oluşturmuştur. Beck Anksiyete Ölçeği (BAÖ) ve Sağlık Çalışanı Güvenliği Ölçeği (SÇGÖ) sorularından oluşan anketten elde edilen veriler SPSS 25 paket programı ile analiz edilmiştir.
\end{abstract}

Anahtar Kelimeler: Mesleki Riskler, İş Stresi, Beck Anksiyete Ölçeği, Sağlik Çalışanları Güvenlik Ölçeği, Sağlık Sektörü

\section{Introduction}

The occupational risks faced by health employees may differ depending on their professional status and departments. Despite the fact that these employees work in different departments, their service in very difficult conditions has a significant effect on their health (Özkan, 2001: 50-57). Various negative situations that may adversely affect health of healthcare professionals bring personal and organizational results. For example, studies have linked workplace exposure to hazardous drugs to skin rashes, unwanted reproductive outcomes (such as infertility, miscarriage and congenital anomalies), leukemia and other cancer possibilities (Akarsu \& Güzel, 2016:12). While risks and hazards in the working environment negatively affect service quality, they can cause perception of stress and anxiety on employess. For this reason, it is necessary to determine the effect of risk and hazard perception arising from working environment of employees on the level of anxiety (Dizili Yelgin et al., 2018: 200-204).

Many different health services are provided in the health sector and various departments are actively working to protect or improve individual health. However, there are several factors that threaten the occupational health and safety of employees. These factors may differ depending on the department where they operate or the device they use. For example, medical instruments in the operating room in hospitals; sterilization of these instruments in sterilization departments; procedures such as blood collection, injection, vascular access, dressing in clinics and polyclinics, and glass materials that are broken or cracked may cause injury in laboratories. The main factors related to the hazards and risks encountered in the health sector are classified as "physical, chemical, biological, ergonomic and psychosocial hazards and risks" (Karacaer et al., 2018: 88-93; Akarsu \& Güzel, 2016:25) 
According to Ergül (2012) perception of stress is quite high due to the characteristics of job and work environment in healthcare institutions. Vital dangers of patients applying to health institutions can create high stress perception on healthcare employees. In addition, the direct communication of health employees with patients and their relatives is among the stress sources. Health employees' perception of stress is higher than those working in other sectors because of individual health and life threats.

On the other hand Kılıç \& İnci (2015) emphasized that it is important to identify various factors affecting the perception of stress of health employees, especially by the management, and to apply preventive measures strategically for these factors in health institutions. It is important that healthcare professionals have necessary knowledge and skills to cope with stress and in-service training in this area. In addition, besides the organizational factors that cause stress, individual factors should be determined and the needs of those working in this direction should be met. Reducing the stress of health employees is seen as important in terms of increasing the quality of service and patient satisfaction.

The purpose of this study is to determine whether the HESS and BAS values differ according to the demographic and job characteristics of the healthcare employees and whether there is a relationship between HESS and BAS.

\section{Material and Methods}

\section{Hypotheses}

Within the scope of the research, 21 hypotheses have been developed and all hypotheses are shown in Table 14.

\section{Universe and Sample}

The population of the study consisted of 294 health employees working in the Artvin State Hospital, where the research was conducted in January - April 2019. In this study, 157 healthcare employees were reached with easy sampling method.

\section{Measuring Tools}

The data of the study was collected by applying the questionnaire consisting of sociodemographic characteristics, risks and dangers arising from hospital working environment, Beck Anxiety Scale (BAS) and Health Employee Safety Scale (HESS). HESS was developed by Öztürk\&Babacan (2012). The reliability coefficient of the scale was found to be 0.96 in this study. BAS was developed by Beck et al. (1988) and is used to determine the anxiety status of individuals. The reliability and validity study of this scale for Turkish was conducted by Ulusoy et al. (1998).

\section{Data Collection and Analysis}

Data were collected on a voluntary basis. SPSS 25 package program was used for analysis of the data. Skewness and Kurtosis values of the scales were used for the normal distribution test. It is assumed that assumption of normality is provided by taking the values between 1.96 and -1.96. Harman's single factor test was used to determine the factor structures of the scale. The scale was analyzed with Cronbach's alpha test for reliability. In the comparison of two variables for difference tests, independent samples t-test was used when the groups showed normal distribution, 
and the groups were analyzed by Mann Whitney $U$ test which is one of the nonparametric tests when they did not show normal distribution. In the comparison of more than two groups, the groups were analyzed by Kruskal Wallis test which is one of the nonparametric tests because they do not show normal distribution. Pearson correlation analysis was used because the variables showed normal distribution to reveal the relationship between the variables. In the hypothesis tests, the data were analyzed by linear regression model because of normal distribution. All results were evaluated at $95 \%$ confidence interval and 5\% significance level.

\section{Limitations of Research}

This study is limited to Artvin Province B Group State Hospital. This includes the health employees working in the hospital (doctor, nurse, midwife, medical secretary, $\mathrm{x}$-ray, anesthesia and laboratory technician). Therefore, the results cannot be generalized to all health professionals. There may be other factors that may affect the risks and hazards that may occur in the work environment and we cannot identify. There is also the possibility that the responses of the employees participating in the survey cannot be completely objective.

\section{Results}

The distribution of the health employees participating in the study according to their sociodemographic characteristics is given in Table 1 .

Table 1. Distribution of Health Employees by Sociodemographic Characteristics

\begin{tabular}{|l|c|c|}
\hline Sociodemographic Characteristics & Number & \% \\
\hline Gender & 116 & 73,9 \\
Female & 41 & 26,1 \\
Male & & \\
\hline Age Groups & 19 & 12,1 \\
$16-25$ & 40 & 25,5 \\
$26-35$ & 60 & 38,2 \\
$36-45$ & 38 & 24,2 \\
46 and over & & \\
\hline Marital Status & 117 & 74,5 \\
Married & 40 & 25,4 \\
Single & & \\
\hline Level of education & 11 & 7,0 \\
High school degree & 66 & 42,0 \\
Associate degree & 61 & 38,9 \\
Bachelor degree & 19 & 12,1 \\
Postgraduate degree & $\mathbf{1 5 7}$ & $\mathbf{1 0 0 , 0}$ \\
\hline Total
\end{tabular}

It was determined that $73.9 \%(\mathrm{n}=116)$ of the participants were female and $26.1 \%$ $(\mathrm{n}=41)$ were male; $12.1 \%(\mathrm{n}=19)$ of $16-25$ years, $25.5 \%(\mathrm{n}=40)$ of $26-35$ years, 
$38.2 \%(\mathrm{n}=60)$ of $36-45$ years of age and $24 \% 2(\mathrm{n}=38)$ were in the 46 and over age range; $74.5 \%(n=117)$ were married and $25.4 \%(n=40)$ were single; $7 \%(n=$ 11) were high school degree, $42 \%(n=66)$ were associate degree, $38.9 \%(n=61)$ were bachelor degree and $12.1 \%$ were postgraduate degree.

Table 2. Distribution of Health Employees' Working Status

\begin{tabular}{|l|c|c|}
\hline Working Status & Number & \% \\
\hline Doctor & 13 & 8,3 \\
Nurse & 60 & 38,2 \\
Midwife & 21 & 13,4 \\
Health Officer & 10 & 6,4 \\
Health Technician & 25 & 15,9 \\
Other & 28 & 17,8 \\
\hline Professional Year & & \\
7 years and less & 50 & 31,8 \\
8-15 years & 39 & 24,8 \\
16-24 years & 47 & 29,9 \\
25 years or more & 21 & 13,4 \\
\hline Working Time & & \\
2 years and less & 55 & 35,0 \\
3-5 years & 38 & 24,2 \\
6-9 years & 32 & 20,4 \\
10 years or more & 32 & 20,4 \\
\hline Department & & \\
Emergency & 19 & 12,1 \\
Service & 18 & 11,5 \\
Polyclinics & 42 & 26,8 \\
Lab & 11 & 7,0 \\
Management / Administration & 22 & 14,0 \\
Other & 45 & 28,7 \\
\hline Total & $\mathbf{1 5 7}$ & $\mathbf{1 0 0 , 0}$ \\
\hline
\end{tabular}

When the statistical distributions are examined according to the working status of the participants,

According to working positions, $8.3 \%$ of them are doctors, $38.2 \%$ are nurses, $13.4 \%$ are midwives, $6.4 \%$ are health officers, $15.9 \%$ are health technicians and $17.8 \%$ are working in other positions.

Table 3. Difference Test Results According to HESS and BAS Scores According to the Sex of the Health Personnel

\begin{tabular}{|l|l|c|c|c|c|c|}
\hline & Gender & $\mathbf{N}$ & Average & Standard deviation & $\mathbf{t}$ & $\mathbf{p}$ \\
\hline \multirow{2}{*}{ HESS } & Female & 116 & 3,09 & 0,82 & \multirow{2}{*}{$-2,113$} & \multirow{2}{*}{0,036} \\
\cline { 2 - 6 } & Male & 41 & 3,43 & 1,06 & & \\
\hline \multirow{2}{*}{ BAS } & Female & 116 & 33,16 & 9,90 & \multirow{2}{*}{3,334} & \multirow{2}{*}{0,001} \\
\cline { 2 - 6 } & Male & 41 & 27,12 & 10,13 & \\
\hline
\end{tabular}


It was determined that there was a statistically significant difference for the HESS and BAS according to the gender of the healthcare employees $(\mathrm{p}<0.05)$. When the group averages are analyzed, it is determined that female participants have a lower average for HESS than male participants, and female participants have higher average for $B A S$ than male participants.

Table 4. Difference Test Results According to HESS and BAS Scores According to Educational Status of Healthcare Employees

\begin{tabular}{|c|c|c|c|c|c|}
\hline & Level of education & $\mathbf{N}$ & Rank average & $\mathbf{X}^{2}$ & p \\
\hline \multirow{4}{*}{ HESS } & High school degree & 12 & 81,92 & \multirow{4}{*}{3,328} & \multirow{4}{*}{,344 } \\
\hline & Associate degree & 65 & 70,28 & & \\
\hline & Bachelor degree & 60 & 83,93 & & \\
\hline & Postgraduate degree & 18 & 83,50 & & \\
\hline \multirow{4}{*}{ BAS } & High school degree & 12 & 68,00 & \multirow{4}{*}{1,539} & \multirow{4}{*}{673} \\
\hline & Associate degree & 65 & 80,40 & & \\
\hline & Bachelor degree & 60 & 79,94 & & \\
\hline & Postgraduate degree & 18 & 69,53 & & \\
\hline
\end{tabular}

According to Kruskal Wallis H test, it was determined that HESS and BAS total scores averages did not show a statistically significant difference according to the educational status of healthcare employees ( $\mathrm{p}>0.05)$.

Table 5. Difference Test Results According to HESS and BAS Scores According to the Professional Experience Status of the Health Employees

\begin{tabular}{|l|l|l|c|c|c|}
\hline & Professional experience & $\mathbf{N}$ & Rank average & $\mathbf{X}^{\mathbf{2}}$ & $\mathbf{p}$ \\
\hline \multirow{4}{*}{ HESS } & 7 years and less & 50 & 66,57 & & \\
\cline { 2 - 5 } & 8-15 years & 39 & 97,37 & \multirow{4}{*}{11,751} & \multirow{3}{*}{008} \\
\cline { 2 - 4 } & 16-24 years & 47 & 82,23 & & \\
\cline { 2 - 4 } & 25 years and over & 21 & 67,24 & & \\
\hline \multirow{4}{*}{ BAS } & 7 years and less & 50 & 77,27 & & \\
\cline { 2 - 4 } & 8-15 years & 39 & 70,53 & \multirow{3}{*}{3,578} & \multirow{3}{*}{, 311} \\
\cline { 2 - 4 } & 16-24 years & 47 & 88,64 & & \\
\cline { 2 - 4 } & 25 years and over & 21 & 77,29 & & \\
\hline
\end{tabular}

According to Kruskal Wallis $\mathrm{H}$ test, it was determined that HESS total scores averages showed a statistically significant difference according to the professional experience of healthcare employees $(\mathrm{X} 2=11.751 ; \mathrm{p}<0.05)$.

While the group with highest average (82.23) is the employees 16-24 years old; the lowest average of the ranks was determined as 66.57 (7 years or less). It was determined that BAS total score averages did not show a statistically significant difference according to the professional experience of the healthcare employees ( $p$ > $0.05)$. 
Table 6. Difference Test Results According to HESS And BAS Scores According to Job Positions of Health Employees

\begin{tabular}{|c|c|c|c|c|c|}
\hline & Working Status & $\mathbf{N}$ & Rank average & $\mathbf{X}^{2}$ & $\mathbf{p}$ \\
\hline \multirow{6}{*}{ HESS } & Doctor & 13 & 74,31 & \multirow{6}{*}{4,034} & \multirow{6}{*}{, 544} \\
\hline & Nurse & 60 & 78,60 & & \\
\hline & Midwife & 21 & 65,07 & & \\
\hline & Health Officer & 10 & 93,80 & & \\
\hline & Technician & 25 & 87,40 & & \\
\hline & Other & 28 & 79,70 & & \\
\hline \multirow{6}{*}{ BAS } & Doctor & 13 & 59,92 & \multirow{6}{*}{7,104} & \multirow{6}{*}{,213 } \\
\hline & Nurse & 60 & 87,16 & & \\
\hline & Midwife & 21 & 89,33 & & \\
\hline & Health Officer & 10 & 72,55 & & \\
\hline & Technician & 25 & 68,90 & & \\
\hline & Other & 28 & 73,95 & & \\
\hline
\end{tabular}

According to Kruskal Wallis $\mathrm{H}$ test, it was determined that HESS and BAS total scores averages did not show a statistically significant difference according to the occupational positions of the healthcare professionals $(\mathrm{p}>0.05)$.

Table 7. Difference Test Results According to HESS and BAS Scores According to Night Shift Frequency of Health Employees

\begin{tabular}{|c|c|c|c|c|c|}
\hline & Night Shift Frequency & $\mathbf{N}$ & Rank average & $\mathrm{X}^{2}$ & $\mathbf{p}$ \\
\hline \multirow{3}{*}{ HESS } & Free & 88 & 78,65 & \multirow{3}{*}{0,109} & \multirow{3}{*}{,947 } \\
\hline & 2 and less & 42 & 80,81 & & \\
\hline & $3-5$ & 27 & 77,31 & & \\
\hline \multirow{3}{*}{ BAS } & Free & 88 & 76,84 & \multirow{3}{*}{1,844} & \multirow{3}{*}{,398 } \\
\hline & 2 and less & 42 & 76,58 & & \\
\hline & $3-5$ & 27 & 89,80 & & \\
\hline
\end{tabular}

According to Kruskal Wallis $\mathrm{H}$ test, it was determined that HESS and BAS total scores averages did not show a statistically significant difference according to the frequency of night shifts of healthcare employees ( $p>0.05)$

Tablo 8. Difference Test Results According to HESS and BAS Scores According to Health Employees' OHS Training Status

\begin{tabular}{|l|l|c|c|c|c|c|}
\hline & Getting OHS Training Status & $\mathbf{N}$ & Average & SD & t & p \\
\hline \multirow{2}{*}{ HESS } & Yes & 78 & 3,29 & 0,98 & \multirow{2}{*}{0,861} & \multirow{2}{*}{, 391} \\
\cline { 2 - 7 } & No & 56 & 3,15 & 0,77 & & \\
\hline \multirow{2}{*}{ BAS } & Yes & 78 & 32,36 & 9,73 & \multirow{2}{*}{1,602} & \multirow{2}{*}{, 111} \\
\cline { 2 - 6 } & No & 56 & 29,66 & 9,45 & & \\
\hline
\end{tabular}


According to independent sample t-test, it was determined that there was no statistically significant difference for HESS and BAS according to the status of health employees receiving OHS training ( $p>0.05$ ).

Tablo 9. Difference Test Results According to HESS and BAS Scores According to the Status of Health Employees Using Personal Protective Equipment

\begin{tabular}{|c|c|c|c|c|c|}
\hline & $\begin{array}{c}\text { Personal Protective Equipment } \\
\text { Usage Status }\end{array}$ & $\mathbf{N}$ & $\begin{array}{c}\text { Rank } \\
\text { average }\end{array}$ & $\mathbf{U}$ & $\mathbf{p}$ \\
\hline \multirow[t]{2}{*}{ HESS } & Yes & 132 & 81,64 & \multirow{2}{*}{$\begin{array}{c}- \\
1,670 \\
\end{array}$} & \multirow{2}{*}{,095 } \\
\hline & No & 25 & 65,08 & & \\
\hline \multirow[t]{2}{*}{ BAS } & Yes & 132 & 76,84 & \multirow{2}{*}{$\begin{array}{c}- \\
1,364\end{array}$} & \multirow{2}{*}{,173 } \\
\hline & No & 25 & 90,36 & & \\
\hline
\end{tabular}

According to Mann Whitney U test, it was determined that there was no statistically significant difference for HESS and BAS according to the PPE usage status of healthcare employees ( $p>0.05$ ).

Table 10. Difference Test Results According To HESS And BAS Scores According To Chronic Disease Status of Health Employees

\begin{tabular}{|c|c|c|c|c|c|c|}
\hline & Chronic Disease Status & $\mathbf{N}$ & Average & SD & t & p \\
\hline \multirow{2}{*}{ HESS } & Yes & 48 & 3,06 & 0,89 & \multirow{2}{*}{$-1,191$} & \multirow{2}{*}{236} \\
\cline { 2 - 6 } & No & 108 & 3,24 & 0,89 & & \\
\hline \multirow{2}{*}{ BAS } & Yes & 48 & 37,79 & 10,15 & \multirow{2}{*}{5,481} & \multirow{2}{*}{000} \\
\cline { 2 - 6 } & No & 108 & 28,80 & 9,14 & & \\
\hline
\end{tabular}

According to independent sample t-test, it was determined that HESS scores did not show a statistically significant difference according to chronic disease states of health employees $(\mathrm{p}>0.05)$.

It has been determined that healthcare employees show a statistically significant difference according to chronic disease status for BAS $(t=5.481 ; p>0.01)$. It was determined that those with chronic disease had a higher average than those without.

Table 11. Difference Test Results According to HESS And BAS Scores According to Mental Illness Status of Health Employees

\begin{tabular}{|c|c|c|c|c|c|}
\hline & Mental Illness Status & $\mathbf{N}$ & Rank average & U & p \\
\hline \multirow{2}{*}{ HESS } & Yes & 9 & 43,33 & \multirow{2}{*}{$-2,406$} & \multirow{2}{*}{, 016} \\
\cline { 2 - 4 } & No & 147 & 80,65 & & \\
\hline \multirow{2}{*}{ BAS } & Yes & 9 & 124,39 & \multirow{2}{*}{$-3,143$} & \multirow{2}{*}{002} \\
\cline { 2 - 4 } & No & 147 & 75,69 & & \\
\hline
\end{tabular}


According to Mann Whitney U test, it was determined that there was a statistically significant difference for HESS $(U=-2,406 ; p<0.05)$ and BAS $(U=-3,143 ; p<0.05)$ according to the mental illness status of healthcare employees. The mean rank of those with mental illness was lower than those without mental illness, while the average values of those with mental illness were higher than rank average of those without mental illness.

Table 12. Difference Test Results According to HESS and BAS Scores According to Thinking Quitting Status of Health Employees

\begin{tabular}{|c|c|c|c|c|c|c|}
\hline & $\begin{array}{c}\text { Thinking Quitting } \\
\text { Status } \\
\end{array}$ & $\mathbf{N}$ & Average & SD & $\mathbf{t}$ & $\mathbf{p}$ \\
\hline \multirow{2}{*}{ HESS } & Yes & 69 & 3,07 & 0,89 & \multirow{2}{*}{1,429} & \multirow{2}{*}{, 155} \\
\hline & No & 86 & 3,28 & 0,90 & & \\
\hline \multirow{2}{*}{ BAS } & Yes & 69 & 34,38 & 11,40 & \multirow{2}{*}{3,080} & \multirow{2}{*}{,002 } \\
\hline & No & 86 & 29,37 & 8,83 & & \\
\hline
\end{tabular}

According to the independent sample t-test, it was determined that HESS scores did not show a statistically significant difference according to the quitting status of healthcare employees. (p>0.05) It was determined that there is a statistically significant difference for BAS according to the status of health workers' quitting status. $(t=3,080 ; p>0,05)$ It has been determined that those who have the idea of quitting their jobs have a higher average than those who do not.

Table 13. Regression Model Results Between HESS and BAS Mean Scores

\begin{tabular}{clllll}
\hline $\begin{array}{l}\text { Dependent } \\
\text { Stress }\end{array}$ & Variable: & Job & & & \multicolumn{2}{c}{$\mathrm{t}$} \\
\hline Constant & $\mathrm{B}$ & Std. D. & Beta & & $\mathrm{p}$ \\
\hline HESS & 37,122 & 2,983 & & 12,445 &, 000 \\
$\mathrm{R}^{2}=0,27$ & $-1,740$ &, 902 &,- 153 & $-1,929$ &, 048 \\
\hline & $\begin{array}{l}\text { Corrected } \\
\mathrm{R}^{2}=0,23\end{array}$ & $\mathrm{~F}=31,721$ & $\mathrm{Sd}=1$ & $\mathrm{p}=0,000$ & \\
\hline
\end{tabular}

As a result of the regression model established, it was determined that the model was meaningful as a whole $(F=31,721 ; p<0.05)$ that the safety of healthcare employees explained the change on the job stress by $23 \%$. It has been determined that the safety of health workers, which is an independent variable, has a statistically significant and negative effect on job stress. $(t=-1.992 ; \mathrm{p}<048)$ 
Table 14. Hypothesis Results

\begin{tabular}{|c|c|}
\hline Hypothesis & Results \\
\hline H1: HESS mean scores differ according to gender of health employees & accepted \\
\hline H2: BAS mean scores differ according to gender of health employees & accepted \\
\hline $\begin{array}{l}\text { H3: HESS mean scores differ according to education level of health } \\
\text { employees }\end{array}$ & rejected \\
\hline $\begin{array}{l}\text { H4: BAS mean scores differ according to education level of health } \\
\text { employees }\end{array}$ & rejected \\
\hline $\begin{array}{l}\text { H5: HESS mean scores differ according to occupational experience of health } \\
\text { employees }\end{array}$ & accepted \\
\hline $\begin{array}{l}\text { H6: BAS mean scores differ according to occupational experience of health } \\
\text { employees }\end{array}$ & rejected \\
\hline $\begin{array}{l}\text { H7: HESS mean scores differ according to occupational position of health } \\
\text { employees }\end{array}$ & rejected \\
\hline $\begin{array}{l}\text { H8: BAS mean scores differ according to occupational position of health } \\
\text { employees }\end{array}$ & rejected \\
\hline $\begin{array}{l}\text { H9: HESS mean scores differ according to frequency of night shift of health } \\
\text { employees }\end{array}$ & rejected \\
\hline $\begin{array}{l}\text { H10: BAS mean scores differ according to frequency of night shift of health } \\
\text { employees }\end{array}$ & rejected \\
\hline $\begin{array}{l}\text { H11: HESS mean scores differ according to whether health employees take } \\
\text { or not OHS training }\end{array}$ & rejected \\
\hline $\begin{array}{l}\text { H12: BAS mean scores differ according to whether health employees take or } \\
\text { not OHS training }\end{array}$ & rejected \\
\hline $\begin{array}{l}\text { H13: HESS mean scores differ according to whether health employees use or } \\
\text { not PPE }\end{array}$ & rejected \\
\hline $\begin{array}{l}\text { H14: BAS mean scores differ according to whether health employees use or } \\
\text { not PPE }\end{array}$ & rejected \\
\hline $\begin{array}{l}\text { H15: HESS mean scores differ according to whether health employees have } \\
\text { or not chronic disease }\end{array}$ & rejected \\
\hline $\begin{array}{l}\text { H16: BAS mean scores differ according to whether health employees have or } \\
\text { not chronic disease }\end{array}$ & accepted \\
\hline $\begin{array}{l}\text { H17: HESS mean scores differ according to mental health status of health } \\
\text { employees }\end{array}$ & accepted \\
\hline $\begin{array}{l}\text { H18: BAS mean scores differ according to mental health status of health } \\
\text { employees }\end{array}$ & accepted \\
\hline $\begin{array}{l}\text { H19: HESS mean scores differ according to whether health employees think } \\
\text { or not quitting job }\end{array}$ & rejected \\
\hline $\begin{array}{l}\text { H20: BAS mean scores differ according to whether health employees think or } \\
\text { not quitting job }\end{array}$ & accepted \\
\hline $\begin{array}{l}\text { H21: Health employees' job safety perception negatively affects workers' job } \\
\text { stress. }\end{array}$ & accepted \\
\hline
\end{tabular}




\section{Discussion}

Health employees' perception of safety is important for the employee's job stress and anxiety about the work environment. Low perceptions of employees regarding their work environment in terms of safety can create psychological pressure on the employees. There are different studies for healthcare professionals (Saygun, 2012; Çakır et al., 2008), managers (Günbayı ve Akcan, 2013; Çelik, 2006) and nurses (Şahin ve Erigüç, 2000; Kaya et al., 2010; Süloğlu, 2009).

According to the study of Tüzüner and Özaslan (2011), the perception of safety climate in the hospital varies significantly compared to the employee groups and departments where they work; on the other hand, their gender, age groups, education levels, total work experiences. It has been determined that there is no significant difference according to the work experience in the health institution. Also it is concluded that the perception of the safety climate of doctors and staff is higher than nurses in the hospitals.

When the scales used in this research are evaluated, the following can be said: Since the internal consistency coefficient for Health Employee Safety Scale is 0.951, this value is above 0.70 , so the reliability of the entire scale can be high. For Beck Anxiety Inventory, the internal consistency coefficient was found to be 0.916 and reliability of the whole scale was quite high.

Similarly Özceylan et al. average score was found to be $3.97 \pm 0.72$ in the study carried out by the health personnel. In this study, the mean score of health personnel was higher.

When the group averages are analyzed, it is determined that female participants have a lower average for Health Employee Safety Scale than male participants, and female participants have higher average for Beck Anxiety Scale than male participants.

According to Karabiber et. al. (2018) study, the average of occupational safety scale score of hospital healthcare professionals is close to half of the full score. The perception of occupational health and safety of female employees, internal employees and those without children is lower.

Similarly, as stated above, the perceptions of occupational health and safety of female participants in this study were lower than that of male employees.

It was determined that the mean of the total scores of the Health Employee Safety Scale and the Beck Anxiety Scale total score did not show a statistically significant difference according to the occupational job positions of the healthcare professionals participating in the research. $(p>0.05)$.

For Beck Anxiety Scale, it was determined that there was a statistically significant difference in terms of health workers' leave of work. $(t=3,080 ; p>0,05)$ According to the groups, it is determined that those who have a thought to quit have a higher average than those who do not have $(\mathrm{p}=0.002)$. 
Özceylan et al. (2018) found higher stress perceptions of nurses who did not intend to quit. In this research, the level of anxiety of the healthcare personnel considering to quit jobs was determined to be higher.

The healthcare personnel who allocated time to rest has higher HESS score than the healthcare personnel who do not take time to rest $(\mathrm{F}=1,995, \mathrm{p}=0,048)$. The healthcare personnel who do not take time to rest have a higher BAS score than healthcare workers who take time to rest $(\mathrm{F}=2.337, \mathrm{p}=0.021)$.

However, in a study conducted by Baykan et al. (2013) in family health center employees, it was shown that there was not enough free time as a reason for burnout occurring in physicians. Rest is seen as an important factor in terms of psychological health of healthcare professionals.

Efforts to improve the working environment conditions, which are considered important on the anxiety states of the employees, gain importance in terms of the performance of the employees. Various negative situations related to health of healthcare employees consider the perception of safety towards working environment and increase the perception of stress. The presence of chronic or mental illness has a positive effect on the perception of stress. In addition, having sleep problems and not having enough time to rest cause stress on health employees.

In the Muşlu et. al. study carried out on 100 nurses in the Primary Health Care Institutions, Training and Research Hospital, no statistically significant difference was found between the study groups in terms of status anxiety, trait anxiety, Back depression scale and SF-36 quality of life scale. However, a statistically significant difference was found between the two groups on the Epworth sleepiness scale ( $p=$ $0.019)$. When the two groups were compared, it was observed that the nurses working in the training and research hospital significantly increased sleepiness and the quality of life decreased more, although it was not statistically significant.

As a result, the risk factors perceived by healthcare employees in the work environment increase the perceptions of the employees towards the work environment. For this reason, the risks and hazards regarding the working environment to health institutions should be minimized. Based on research results, some issues to be considered in health institutions can be summarized as follows. Risks and hazards should be determined by the managers in health institutions and necessary preventive measures should be taken. Night shifts should be properly prepared and planned to ensure that healthcare professionals rest. Policies to reduce workload should be determined. Occupational health and safety trainings should be provided. 


\section{REFERENCES}

Akarsu, Handan; Güzel, Münevver (2016). "Sağlık Sektöründe Tehlike ve Riskler", Çalışma ve Sosyal Güvenlik Eğitim ve Araştırma Merkezi Yayınlarl, Erişim tarihi: 06.02.2020, http://isg.amasya.edu.tr/media/1273/sag1\%C4\%B1ksektoerue.pdf.

Baykan, Zeynep; Çetinkaya, Fevziye; Naçar, Melis; Kaya, Alper; Iş1ldak, M. Ümit (2013). "Aile Hekimlerinin Tükenmişlik Durumları ve İlişkili Faktörler”. Antalya: 16. Ulusal Halk Sağlığı Kongresi.

Beck, Aaron T.; Epstein, Norman; Brown, Gary; Steer, Robert A. (1988). "An Inventory For Measuring Clinical Anxiety: Psychometric Properties", Journal of Consulting and Clinical Psychology, Cilt: 56, Say1: 6, s.893-897.

Çakır, Aysun; Çırak, Süleyman; Çelik, Emel; Kaykaç, Funda (2008). "Acıbadem Sağlık Grubunda Çalışan Klinik Eğitim Hemşirelerinin Stres Kaynaklarının ve Stres İle Baş Etme Yollarının Belirlenmesi", IV. Ulusal Hemşirelik Eğitim Kongresi, Erişim tarihi: 15.06.2019, http://www.acibademhemsirelik.com/bilimsel_calisma/keh_stres_ka ynaklari.pdf

Çelik, Celal Kadir (2006). Eğitim Yöneticilerinin Mesleki Tükenmişlikleri İle Evlilik Doyumları Arasındaki İlişki, Gaziosmanpaşa Üniversitesi Sosyal Bilimler Enstitüsü Yayımlanmamış Yüksek Lisans Tezi, Tokat.

Dizili Yelgin, Canan; Çıkman, Aytekin; Karakeçili, Faruk; Gülhan, Barış; Aydın, Merve (2018). "Bir Eğitim ve Araştırma Hastanesinde Kesici ve Delici Alet Yaralanmalarının Değerlendirilmesi”. Klimik Dergisi, Cilt:31, Say1:3, s. 200-204.

Ergül, Adem (2012). Çalışma Yaşamında Stresin Bireysel Performans Üzerindeki Etkileri: Eğitim ve Sağlık Çalışanlarına Yönelik Bir Araştırma. Balıkesir Üniversitesi Sosyal Bilimler Enstitüsü Yayımlanmamış Yüksek Lisans Tezi, Balıkesir.

Günbay1, İlhan; Akcan, Fatih (2013). "İlköğretim Kurumları Yöneticilerinin Yaşadıkları İș Streslerine İlișkin Görüșleri: Bir Durum Çalıșması". Journal of Teacher Education and Educators, Cilt: 2, Say1:2, s.195224.

Karabiber, Cansu; Sarb, Gülay; Kerman, Beyza; Savaş, Nazan (2018). "Bir Tıp Fakültesi Hastanesi Sağlık Çalışanlarında İş Sağlığı-Güvenliği Durumu ve Risk Faktörleri”, HSP, Cilt: 5, Sayı:3, s.367-375. 
Karacaer, Zehra; Diktaş, Hüsrev; Tosun, Selma (2018). "İkinci Basamak Sağlık Kuruluşunda Sağlık Personeli Arasında Kesici ve Delici Alet Yaralanmaları Sıklığı ve İlişkili Risk Faktörleri”. Klinik Dergisi, Cilt:31, Say1: 2, s.88-93.

Kaya Nurten; Kaya, Hatice; Ayık Erdoğan Saliye; Uygur, Esma (2010). "Bir Devlet Hastanesinde Çalışan Hemşirelerde Tükenmişlik", Uluslararası Bilim Dergisi, Cilt: 7, Sayı:1, s. 401-419.

Kılıç, Cengiz; İnci, Figen (2015). "Acil Tıp Çalışanlarında Travmatik Stres: Yaş ve Eğitimin Koruyucu Etkisi”, Türk Psikiyatri Dergisi, Cilt:26, Say1:4, s.236-241.

Muşlu, Cemil; Baltacı, Davut; Kutanis, Remzi; Kara, İsmail Hamdi (2012). "Birinci Basamak ve Hastanede Çalışan Hemşirelerde Anksiyete, Depresyon ve Hayat Kalitesi”, Konuralp Tip Dergisi, Cilt: 4, Sayı:1, s.17-23.

Özceylan, Eren; Korkmaz, İbrahim Halil; Özceylan, Ayca; Kırımoğlu, Sevcan (2018). "Sağlık Çalışanlarının İş Güvenliği Algılarının İş Stresi Düzeylerine Etkisi: Gaziantep'te Bir Özel Hastane Örneği”. Türk Sosyal Bilimler Araştırmaları Dergisi, Cilt:3, Sayı:1, s.38-52.

Özkan, Özlem (2001). "Sağlık Çalışanlarının Sağlığı/Güvenliği İçin İşyeri Örgütlenme Birimi”, 2. Ulusal Sağlık Çalışanları Sağlığı Kongresi, Ankara, s.50-57.

Öztürk, Havva; Babacan, Elif (2012). "Bir Ölçek Geliştirme Çalışması: Hastanede Çalışan Sağlik Personeli İçin İş Güvenliği Ölçeği", Hemşirelikte Ĕ̈itim ve Araştırma Dergisi, Cilt: 9, sayı:1, s. 36-42.

Saygun, Meral (2012). "Sağlık Çalışanlarında İş Sağllğı ve Güvenliği Sorunları", TAF Preventive Medicine Bulletin, Cilt: 11, Sayı:4, s. 373382.

Şahin, Hülya; Erigüç, Gülsün (2000). "Hastane Yöneticileri Yönetsel Stres Kaynakları Belirtileri ve Başa Çıkma Yöntemleri", Hacettepe Sağllk İdaresi Dergisi, Cilt:5, Sayı:2, s. 21-53.

Süloğlu, Aysun (2009). Diyaliz Merkezlerinde Çalışan Doktor ve Hemşirelerde Tükenmişlik Sendromu. Uzmanlık Tezi, Sağlık Bakanlığı Bakırköy Dr. Sadi Konuk Eğitim ve Araştırma Hastanesi Aile Hekimliği, İstanbul.

Tüzüner, Vala Lale; Özaslan, Burcu Özge (2011). "Hastanelerde İş Sağlığı ve Güvenliği Uygulamalarının Değerlendirilmesine Yönelik Bir 
Araştırma”, İstanbul Üniversitesi İşletme Fakültesi Dergisi, Cilt:40, Say1:2, s. 138-154.

Ulusoy, Muhterem; Şahin, Nesrin Hisli; Erkmen, Hüsnü (1998). "Turkish Version of The Beck Anxiety Inventory". Journal Cognitive Psychother, Cilt:12, Say1:2, s. 163-172. 